\title{
The Inscription Nr. 6858 from Kjolmen (Bulgaria)
}

\author{
Reinhardt S. Stein 1, Giancarlo T. Tomezzoli² \\ ${ }^{1}$ Portland State University, Portland, OR, USA \\ ${ }^{2}$ Etno-Archaeological Observatory, Munich, Germany \\ Email: rstein@psu.edu,gt21949@gmx.de
}

How to cite this paper: Stein, R. S., \& Tomezzoli, G. T. (2017). The Inscription Nr. 6858 from Kjolmen (Bulgaria). $A d$ vances in Anthropology, 7, 289-297. https://doi.org/10.4236/aa.2017.74016

Received: July 28, 2017

Accepted: October 16, 2017

Published: October 19, 2017

Copyright (C) 2017 by authors and Scientific Research Publishing Inc. This work is licensed under the Creative Commons Attribution International License (CC BY 4.0).

http://creativecommons.org/licenses/by/4.0/

\section{(c) (i) Open Access}

\begin{abstract}
The inscription 6858 was discovered on a grave slab at the beginning of 1965, $1 \mathrm{~km}$ far from the village of Kjolmen (Preslav district-Bulgaria). After having considered previous decipherings, we propose a deciphering based on similarities between the inscription characters and characters in the Greek alphabets and on similarities of its words with words in present, surviving Slavic languages. The inscription meaning is: this is the tomb of Ebavo son of Zesasha and in the grave is too Ilasi wife of Leteda and daughter to me, which indicates that, originally, the slab was inscribed in a non-survived Proto-Slavic language. This indicates that the inscription originated from a Proto-Slavic culture which settled in the southern part of the Balkan area during the $6^{\text {th }}-5^{\text {th }}$ cen. BC, i.e. well before the $7^{\text {th }}$ cen. AD the generally accepted period of the Slavs arrival in Eastern Europe, and represents an invitation to make efforts for exploring the presence and development of Proto-Slavic cultures in the Balkan area, Europe and Middle-East in the antiquity.
\end{abstract}

\section{Keywords}

Cremation, Grave, Tomb, Inscription, 6858, Kjolmen, Preslav, Bulgaria, Proto-Slavic, Slavic

\section{Introduction}

The inscription was discovered on a grave slab at the beginning of 1965, $1 \mathrm{~km}$ far from the village of Kjolmen (Preslav district-Bulgaria) (Beševliev, 1965; Schmitt-Brandt, 1967; Ancillotti, 1986; Woudhuizen, 2000-2001). The grave, covered by a low tumulus, was destroyed by a deep tractor-ploughing and recognized from its broken rests found in the surroundings. The slab covered the grave, with the inscribed side facing its interior, together with other two unin- 
scribed slabs (Beševliev, 1966).

The grave, according to the rests found, contained a small metal plates armour, a spear tip, a sword, an amphora and broken earthen vases (Beševliev 1965; Ancillotti, 1986) or another clay pot (Schmitt-Brandt, 1967). Because no skeletal remains were traced, it is assumed that the burial rite was cremation (Beševliev, 1965; Woudhuizen, 2000-2001).

The age assigned to the grave is the $6^{\text {th }}$ cen. BC on the basis of preliminary analyses of its content (Woudhuizen, 2000-2001), which was coherent with the typology of the Thracian burials for a territory intermediate, in the antiquity, between those of the Thracian tribes of Krobuzoi and Artakioi (Ancillotti, 1986). The inscription characters are typical of the $6^{\text {th }}-5^{\text {th }}$ cen. BC (Beševliev, 1965) or the $4^{\text {th }}-5^{\text {th }}$ cen. BC (Schmitt-Brandt, 1967) or of a Greek variety of the $5^{\text {th }}$ cen. BC with features corresponding totally and exclusively to none of the known ancient Greek alphabets (Ancillotti, 1986).

The slab is formed by a big part $(1.42 \times 0.735 \times 0.123 \mathrm{~m})$ and small part $(0.725$ $\times 0.56 \mathrm{~m}$ ) (Beševliev, 1965). The first part of the inscription starts close to a long side of the slab big part, crosses it diagonally towards the slab small part. Then, on the slab small part it follows a semi-circle turning back towards the slab big part. The inscription second part is inside the semi-circle (Figure 1). The inscription first part is $1.42 \mathrm{~m}$ long and is formed by 51 characters; the inscription second part is $0.30 \mathrm{~m}$ long and is formed by 9 characters. The high of the characters varies between 25 and $60 \mathrm{~mm}$ (Beševliev, 1965).

The slab, initially at the Preslav Museum (Inv. Nr. 3311), is now at the Sofia Archaeological Museum (Inv. Nr. 6858).

\section{Proposed Decipherings}

Several very interesting attempts, sometime successful, have been made in the past for deciphering the inscription. The following are the most relevant.

a) (Beševliev, 1965)

1) // $\Lambda \mathrm{A} \Sigma / / \Lambda \mathrm{ETE} \Delta / / \Lambda \mathrm{E} \Delta / / \mathrm{E \Pi I} \triangle \mathrm{AKATPOŚOEBATO} \Sigma \mathrm{E} \Sigma \mathrm{AS} / / \mathrm{H} / /$ ETE $\Sigma$ AIГEKOA

2) // B $\triangle \mathrm{ABAN \Gamma} \mathrm{//}$

b) (Georgiev, 1966)

1) EBAP. ZE $\Sigma A \Sigma N$ HNETE $\Sigma$ A IГEK. A

2) $\mathrm{NB} \Lambda \mathrm{ABAHГN}$

3) NYA $\Sigma$ N $\Lambda$ ETE $\Delta$ N $Y$ ENEIN $\Delta$ AKATP. $\Sigma$

Ebar (son) of Zesa(s) I 58 years lived here. Do not damage this (grave?)! Do not desecrate the deceased, for this (the same) will be done to you!

c) (Schmitt-Brandt, 1967)

EBAPOZE $\Sigma A \Sigma N$ HN ETE $\Sigma$ A IГEKOA

$\mathrm{NB} \Lambda \mathrm{ABAH \Gamma N}$

NYA $\Sigma$ N $\Lambda$ ETE $\Delta$ NYE $\Delta$ NENIN $\Delta$ AKATPO $\Sigma \mathrm{O}$

Hebros, the son of Zesas I am, 58 year I have seen (or: counted). 
Cause no damage!

No own funerary vase should be placed here inside.

d) (Ancillotti, 1986)

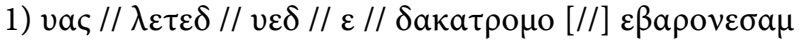

2) $\mathrm{H} / / \varepsilon \tau \varepsilon \sigma \alpha / /$ aко $\alpha$

3) // $\beta \lambda \alpha \beta \alpha / / \mathrm{H} / /$

Compensation from own patrimony if in my sepulchre they have deposed a corpse: 8 (monetary units) to the tribe and 3 (monetary units) to the supra-tribal league. Mulct of 8 and 3.

e) (Schmid, 1987)

1) EBAPOZE $\Sigma A \Sigma N H N E T E \Sigma A I \Gamma E K O A$

2) $\mathrm{NB} \Lambda \mathrm{ABAH \Gamma N}$

3) NYA $\Sigma$ N $\Lambda$ ETE $\Delta$ NYE $\Delta$ NENIN $\triangle A K A T P O \Sigma O$

I, Ebryzes, lived 58 years. Now I am sinking in the Lethe, I died here in battle. One should (to the monument) no damage.

f) (Orel, 1995-1997)

1 [-]yas//[-]eted//yed//ei//dakatrośo[-]

[-]esaś//ē//[---]ekoa[-] 2 //blabaēs//

(I) ebaro[y] esaś ē e[g]esa[ti] ekoa[i]

(II) blabaes

(III) yas [y] eted yed ei dakatr oso[-]

Esas made (this tombstone) for Ebros, for Ekwa('s sake). (She) barred the way of that (one) who trespasses (?) and causes (harm, damage?).

g) (Woudhuizen, 2000-2001)

1) //cas//leted//ced//e///dakatdoso[//]ebalozesas//

2a) ////etesa//ekoa

2b) $/ / \mathrm{c} / / \mathrm{abacb} / /$

This stone (monument), Ebalo, (the son) of Zesa has made (it) as a gift

2a) for the annual/yearling Mare 2b) (abecedarium)

h) (Dimitrov, 2003)

1) I $\Lambda \mathrm{A} \Sigma \mathrm{N} \Lambda \mathrm{ETE} \Delta \mathrm{N} \Lambda \mathrm{E} \Delta \mathrm{NENI} \Delta \mathrm{AKATPO} \Sigma \mathrm{O}$

2) $\operatorname{EBAPOZE} \Sigma A \Sigma N H N E T E \Sigma A I \Gamma E K O A$

3) NB $\triangle A B A H Г N$.

i) (Theodossiev, 1997; Theodossiev, 2010)

$/ / \mathrm{YA} \Sigma / / \Lambda \mathrm{ETE} \Delta / / \mathrm{YE} \Delta / / \mathrm{E} / / / \Delta \mathrm{AKATP} \cdot \mathrm{I} \cdot \mathrm{EBA} \cdot \mathrm{NE} \Sigma \mathrm{AI} / / \mathrm{H} / /$

$\mathrm{ETE} \Sigma \mathrm{A} / \Gamma \mathrm{EK} \cdot \mathrm{A} / / \mathrm{B} \Lambda \mathrm{ABAN} \Gamma / /$

$\mathrm{A} \cdot \mathrm{KE} / \mathrm{A} \Sigma \mathrm{ETE} / / \mathrm{H} / / \mathrm{IA} \Sigma \mathrm{EN} \cdot \Gamma \mathrm{ABE} \cdot \mathrm{I} \cdot \mathrm{PTAKA} \Delta / / / \mathrm{E} / / \Delta \mathrm{EY} / / \Delta \mathrm{ETE} \Lambda / / \Sigma \mathrm{AY} / /$

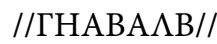

All these deciphering attempts are highly appreciable but pose some problems. Although all based on similarities with elements in the spoken languages of $6^{\text {th }}-5^{\text {th }}$ cen. BC, no one of them confirms another one. Only three (Ancillotti, 1986; Woudhuizen, 2000-2001; Theodossiev, 1997; Theodossiev, 2010) address concretely the mystery of the slab inscribed side facing the interior of the grave 
and provide different explanations. Each one identifies a different inscription source language: a language of either a mixed tribe established in the region of the discovered grave or of an unknown warrior, who came from outside the region (Beševliev, 1965); a Thracian, (Daco) Moesian crossing dial. (Georgiev, 1966), the Thracian language (Schmitt-Brandt, 1967); a non-Greek language-a Thracian dial. (Ancillotti, 1986); a language between Greek and Indo-Iranian (Schmid, 1987); a language close to the O. Phr. and N. Phr. (Orel, 1995-1997); a blend of Phrigianising and Luwianising elements (Woudhuizen, 2000-2001); the Thracian language (Dimitrov, 2003). However, no one considers the ProtoSlavic nature of the inscription, as we will see soon.

\section{Deciphering}

\subsection{Reading}

The inscription is written in continuo, i.e. without separation between the words.

The phonetic value of the inscription characters (Figure 1) can be derived mainly from the phonetic values of corresponding, similar characters in the ancient Greek alphabets, the closest alphabets to that of the inscription, as well as from similarities with elements in the present surviving Slavic languages. The different orientation of some characters, for example A, B and L, appears merely due to the oestrus of the engraver rather than indicate possible inscription reading directions. The character // is: i; /// is: in; the sigma represented by four or six strokes (Woudhuizen, 2000-2001) correspond, respectively, to a phonetic normal sigma and to a sigma having the reinforced phonetic value of: sh or shch, corresponding to the present Russ. characters $ш$ or щ; $j$ would have the phonetic value of the Rus. ж.

The inscription begins on the slab small part at the beginning of the semi-circle because of the pers. $n$. present there indicating the deceased and the possible offeror. The inscription reading is the following (Figure 1):

\section{ebavozesashijietesarekoaivjabalbiilasiletediledieindakatrosho}

This, on the basis of similarities with elements in the surviving Slavic languages, can be separated in words as follows:

\section{Ebavo Zesashi jiete sa rekoa i v jaba lbi Ilasi Letedi ledi ein dakatro sho}

\subsection{Interpretation}

Ebavo: pers. n.; linked to the later O. Ch. S. v. єббать = to copulate; similar also to the Thracian or (Daco)Moesian pers. n. Ebrenus, $\mathrm{E} \beta \rho / \varepsilon / v \varepsilon o c$, Hebrenus (Georgiev, 1966) and the Thracian pers. n. Eßpoc (Orel, 1995-1997).

Zesashi: pers. $n$. in gen. case; linked to the later O. Ch. Sl. сїғть = to shine; similar also to the Thracian or (Daco) Moesian pers. n. ZE $\sum$ A (Georgiev, 1966) and the Thracian pers. n. Zeizas, Zeisis (Woudhuizen, 2000-2001).

jiete: subst. child, son; similar to Bel. дзіця = child; Blg. дете; Bos. dete; Cr. 


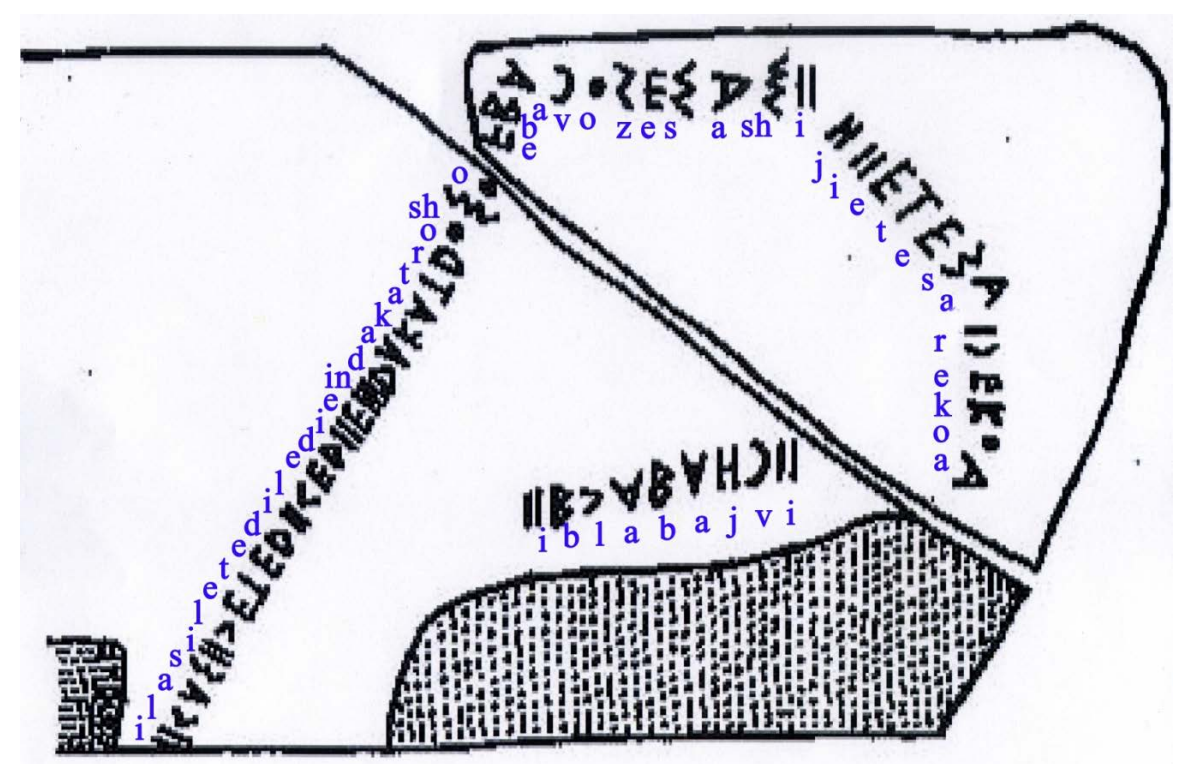

Figure 1. Reading of the Kjolmen inscription (start image Woudhuizen, 2000-2001).

dijete; Cz. dítě; Luz. dźéćo; Mac. = дете; Pol. dziecko; Rus. дитя; Ser. дете; Slov. dieta; Ukr. дитя.

sa: dem. pron. $=$ this; similar to O. Blg. se $=$ this one; $\mathrm{O}$. Ch. Sl. $c \epsilon=$ this; Rus. сей $=$ this; Ukr. = це.

rekoa: subst. $=$ tomb; similar to O. Blg. рака $=$ grave, ditch; Rus. рака $=$ grave, reliquary; Lith. rakti-to dig.

i: conj. = and; coincident with Bel. и = and; Bos. і; Mac. и; Pol. і; Rus. и; Ser. и, Slo. in; Ukr. и.

v: prep. = in; similar to Blg. в = in; Mac. во; Pol. w; Rus. в; Slo. v; Slov. v; Ukr. в.

jaba: subst. = grave, place; similar to Blg. лоб = bottom; Lith. lobas = abyss; Rus. dial. лабца = marshy place.

lbi: unknown in surviving Slavic languages; probably corresponding to the conj. also, too.

Ilasi: pers. n.; probably linked to the subst. force; similar to Bel. сіла = force; Bos. sila; Blg. сила; Cr. sila; Mac. сила; Pol. siła; Rus. сила; Ser. сила; Slo. sila; Slov. sila; Ukr. сила.

Letedis: pers. $\mathrm{n}$. in gen. case (?); probably linked to the subst. summer, the season of his birth; similar to Bel. леta = summer; Bos. leto; Blg. лято; Cr. lejeto; Мас. лето; Pol. lato; Rus. лето; Ser. лето; Slo. poletje; Slov. letné; Ukr. літо.

ledi: $\mathrm{n}$. wife; similar to O. Rus. лада $=$ wife and also to the Lyc. lada $=$ wife. ein: dem. pron.; similar to Blg. dial. еи = this, here.

dakatro: subst. daughter; similar to Bel. дочка = daughter; Cz. dcera; Lith. dukterinë; O. Ch. Sl. дістєрє; Rus. дочь; Ser. Ћерка; Slov. dcéra; Ukr. дочка.

sho: poss. pron. with me in the sense of to me, my; similar to Bel. са мной = with me; Bos. sa mnom; Bul. с мен; Cr. sa mnom; Lith. su manimi; Mac. со мене; Rum. cu mine; Rus. со мной; Ser. са мном; Slo. z mano; Slov. so mnou; Cz. se mnou; Ukr. зі мною. 


\subsection{Translation}

On the basis of the above reading and interpretation, the inscription can be translated as:

This is the tomb of Ebavo son of Zesasha and in the grave is also Ilasi wife of Leteda and daughter to me.

\subsection{Discussion}

Our deciphering indicates that originally the slab was inscribed in a non-survived Proto-Slavic language originated in a non-survived Proto-Slavic culture. The inscribed slab originally was probably commissioned by Zesasha as tomb cover of a grave containing the corpses of his son Ebavo and his daughter Ilasi although "to me" let the doubt of a possible different offeror. The inscribed side of the slab, or its inscribed parts (Georgiev, 1966), was/were at the origin facing the outside of the grave for indicating to the visitors the buried persons and the offeror. It is not excluded that on its central part a movable object was posed (Woudhuizen, 2000-2001), so that it also fulfilled the role of pedestal for said object. Subsequently, the inscribed slab, or its inscribed parts, was/were used to cover the grave of a soldier or a military commander whose arms were placed in the grave. In this case the offeror or offerors (his companions? his soldiers?) was/were illiterate, but well aware of the extraneous nature of the inscription with respect to the deceased, thus, he/they decided to put the slab inscribed side, or its inscribed parts, facing the inside of the grave before to cover it with a tumulus.

The presence of a non-survived, ancient Proto-Slavic culture in present East Bulgaria is not surprising because of the presence in the South-Balkan area of other ancient Proto-Slavic cultures as recently recognized by several authors through the deciphering of Old-Phrygian, South Balkan, Minoan and Linear A inscriptions based on their similarities with elements in the present, surviving Slavic languages (Ambrozic, 2002; Ambrozic, 2005; Serafimov, 2007a; Serafimov, 2007b; Serafimov \& Perdih, 2009; Serafimov \& Tomezzoli, 2011; Serafimov \& Tomezzoli, 2012; Tomezzoli \& Serafimov, 2013; Stein \& Tomezzoli, 2016). The comparison of the inscription language with present surviving Slavic languages is obliged because ancient, written Proto-Slavic documents and/or documents from cultures not yet formally recognized as Proto-Slavic, rarely survived because written on perishable supports, like leaves, birch bark, wooden boards and animal skins. Only in few cases, they survived, because written on non-perishable supports, like ceramic (Tomezzoli \& Serafimov, 2013; Tomezzoli \& Stein, 2016), golden artifacts (Serafimov, 2007a; Serafimov \& Tomezzoli, 2012) and on the slab covering the grave near Kjolmen.

\section{Conclusion}

The arguments developed in this article indicate that the culture from which the inscription originated was an ancient non-survived Proto-Slavic culture, which 
settled in the southern part of the Balkan area during the $6^{\text {th }}-5^{\text {th }}$ cen. BC, i.e. well before the $7^{\text {th }}$ cen. $\mathrm{AD}$ the generally accepted period of the Slavs arrival in Eastern Europe and invite to make efforts for identifying and studying ancient Proto-Slavic inscriptions, which are fundamental for understanding the presence and development of Proto-Slavic cultures in the Balkan area, Europe and Middle-East areas in the antiquity.

\section{References}

Ambrozic, A. (2002). Gordian Knot Unbound. Toronto: Cythera Press.

Ambrozic, A. (2005). The "Warrior" Stele from Lemnos. Proceedings of the Tenth International Topical Conference Ancient Settlers of Europe, Ljubljana, 10-11 June 2005, 107-120. http://www.korenine.si/zborniki/zbornik05/ambrozic_warrior.pdf

Ancillotti, A. (1986). Una nuova lettura dell'iscrizione di Kjolmen. Archivio Glottologico Italiano, 71, 1-14.

Beševliev, V. (1965). Inschrift in unbekannter Sprache aus Bulgarien. Linguistique Balkanique, 11, 5-8.

Beševliev, V. (1965). Inschrift in unbekannter Sprache aus Nordbulgarien. Glotta, 43, 317-322.

Dimitrov, P. A. (2003). The 6th cen. BC Inscription from Kjolmen, District of Preslav, North-Eastern Bulgaria (Archeological Museum of Sofia, inv: No. 6558). Thracia 15. In Honour of Alexander Fol's $70^{\text {th }}$ Anniversary, 345-354.

Georgiev, V. I. (1966). Die Deutung der altertuemlihen trakischen Inschrift aus Kjolmen. Linguistique Balcanique, 11, 9-23.

Orel, V. (1995-1997). The Inscription from Kjolmen. Mediterranean Language Review, 9, $79-82$.

Schmid, W. P. (1987). "Zur Thrakischen Grabinschrift Aus Kölmen”. Zeitschrift Für Vergleichende Sprachforschung, 100, 351-357. www.jstor.org/stable/40848883

Schmitt-Brandt, R. (1967). Die thrakischen Inschriften. Glotta, 45, 1-2, 40 -60.

Serafimov, P. (2007a). New Reading of the Thracian Inscription on the Golden Ring from Ezerovo. In Proceedings of the 5th International Topical Conference Origin of Europeans (pp. 176-183). Založništvo Jutro.

http://www.korenine.si/zborniki/zbornik07/serafimov_ezer07.pdf

Serafimov, P. (2007b). Translation of Eteocretan Epioi Inscription. In Proceedings of the 5th International Topical Conference Origin of Europeans (pp. 199-206). Založništvo Jutro. http://www.korenine.si/zborniki/zbornik07/serafimov_epioi07.pdf

Serafimov, P., \& Perdih, A. (2009). Translation of the Linear Tablet HT 13 from Crete. In Proceedings of the 7 th International Topical Conference Origin of Europeans (pp. 58-73). Založništvo Jutro. http://www.korenine.si/zborniki/zbornik09/seraf_ht13.pdf

Serafimov, P., \& Tomezzoli, G. T. (2011). Evidence for Early Slavic Presence in Minoan Crete. In Proceedings of the 9 th International Topical Conference Origin of Europeans (pp. 219-229). Založništvo Jutro.

http://www.korenine.si/zborniki/zbornik11/serafimov_slavic_crete.pdf

Serafimov, P., \& Tomezzoli, G. T. (2012). New Reading of the Linear a Inscription on the Golden Pin CR-ZF-1 from Crete. In Proceedings of the 10 th International Topical Conference Origin of Europeans (pp. 83-89). Založništvo Jutro.

Stein, S. R., \& Tomezzoli, G. T. (2016). The Inscription of Parvomai. Advances in An- 
thropology, 6, 25-29. https://doi.org/10.4236/aa.2016.62003

Theodossiev, N. (1997). A New Early Thracian Inscription from Bulgaria. In Kadmos Zeitschrift für vorund frühgriechische Epigraphik (p. 36).

Theodossiev, N. (2010). On the Reading and Date of the Kjolmen Inscription. De Gruyter Wissenschaftsverlag, 102, 216-229.

Tomezzoli, G. T., \& Stein, R. S. (2016). The Philistine Inscription 4.5 from Ashkelon (Israel). Advances in Anthropology, 6, 45-50. https://doi.org/10.4236/aa.2016.63006

Tomezzoli, G., \& Serafimov, P. (2013). The Linear a Inscriptions II.1, II.2 from the Palace of Knossos. In Proceedings of the 11 th International Topical Conference Origin of Europeans (pp. 105-114). Založništvo Jutro.

Woudhuizen, F. C. (2000-2001). The Earliest Inscription of Thrace. TALANTA, 32-33, 289-305. 


\section{List of Abbreviations}

$\begin{array}{ll}\text { Bel. } & \text { Belarussian } \\ \text { Blg. } & \text { Bulgarian } \\ \text { Bos. } & \text { Bosnian } \\ \text { cen. } & \text { Century } \\ \text { conj. } & \text { Conjunction } \\ \text { Cr. } & \text { Croatian } \\ \text { Cz. } & \text { Czech } \\ \text { dem. pron. } & \text { Demonstrative pronoun } \\ \text { dial. } & \text { Dialect, dialectal } \\ \text { gen. } & \text { Genitive } \\ \text { Lith. } & \text { Lithuanian } \\ \text { Luz. } & \text { Luzatian } \\ \text { Lyc. } & \text { Lycian } \\ \text { Mac. } & \text { Macedonian } \\ \text { n. } & \text { Name } \\ \text { N. Phr. } & \text { New Phrygian } \\ \text { O. Blg. } & \text { Old Bulgarian } \\ \text { O. Ch. Sl. } & \text { Old Church Slavonic } \\ \text { O. Phr. } & \text { Old Phrygian } \\ \text { O. Rus. } & \text { Old Russian } \\ \text { pers. n. } & \text { Personal name/s } \\ \text { pers. pron. } & \text { Personal pronoun } \\ \text { Pol. } & \text { Polish } \\ \text { poss. pron. } & \text { Possessive pronoun } \\ \text { prep. } & \text { Preposition } \\ \text { Rum. } & \text { Rumanian } \\ \text { Rus. } & \text { Russian } \\ \text { Ser. } & \text { Serbian } \\ \text { Slo. } & \text { Slovenian } \\ \text { Slov. } & \text { Slovakian } \\ \text { subst. } & \text { Substantive } \\ \text { Ukr. } & \text { Ukrainian } \\ & \\ \text { Lom }\end{array}$

